\title{
To Be a Box or Not to Be a Box: The Multiple Meanings of the Metaphor in Antoni Tàpies
}

\author{
Fernando Echarri ${ }^{1, *}$, Victor Echarri' \\ ${ }^{1}$ University of Navarra Museum, University of Navarra, Pamplona, Spain \\ ${ }^{2}$ Department of Architectural Constructions, University of Alicante, Alicante, Spain \\ Email address: \\ fecharri@unav.es (F. Echarri), victor.echarri@ua.es (V. Echarri) \\ ${ }^{*}$ Corresponding author
}

To cite this article:

Fernando Echarri, Victor Echarri. To Be a Box or Not to Be a Box: The Multiple Meanings of the Metaphor in Antoni Tàpies. International Journal of Literature and Arts. Vol. 7, No. 6, 2019, pp. 132-138. doi: 10.11648/j.ijla.20190706.11

Received: September 17, 2019; Accepted: October 5, 2019; Published: October 16, 2019

\begin{abstract}
The reality that surrounds us throws us continuous messages that are perceived by our senses. In this perception, sight is configured as a principal sense capable of obtaining many of these messages and generating, from these perceptions, numerous thoughts, feelings and emotions. In this way, the routine of I see-thought-question- is established. The education of the gaze then becomes a matter of first order to favor the understanding of our world. Art, as a form of reality, or as an adaptation of reality, can be used as a tool to promote a different way of looking, it can be a discipline that can help to understand our reality. The following article studies the metaphor as a possible resource for the awareness of reality. An example of a metaphor, its possibility of inquiry, and discovery of meaning is the artwork Composicio amb cistella made in 1996 by Antonio Tàpies, which is part of the collection of the University of Navarra Museum. The Catalan artist uses metaphor in this sculpture trying to deceive the eye that looks at it, in an attempt to encourage participation and reflexive activation of visitors to the Museum. The conceptualization of the sculpture is specifically studied, in a synthetic way, through a philosophical approach on the aesthetic and the metaphor contributed by José Ortega y Grasset. The aim is to get support from aesthetic- philosophical which helps explore the possibilities of the metaphor as an aesthetic resource for the awareness of reality.
\end{abstract}

Keywords: Gaze Education, Aesthetic Education, Metaphor, Ortega Y Gasset, Tàpies

\section{Educating the Eyes for Every Day and for Art}

The tangible reality that surrounds us gets our attention [1] and continually provides us messages [2] creating interactive responses, some as perceptions that allow different knowledge on objects [3]. When it comes to perception, it's fundamentally performed through our senses, the most significant sense being the sight. For Cossio [4] it is "the first and inaudible condition of knowledge"; in short, the start of the "visual thinking [5]" that generates a thinking routine "I see-I think-I ask". However, our visual perception, like the rest of our senses, easily accommodate to what is known [6]. Therefore, it needs to go back and focus its attention to be able to deeply search and analyze reality, being aware of the details that allows the awaken of astonishment [1] and obtaining the maximum meaning in the immanence of things. Many artists try to transmit the importance of learning to see, and the education of the eyes. For example, Manrique incites to acutely wake up the "capacity of looking and feeling astonishment and consciousness of everything we possess [7]". The importance of looking is such that Tàpies qualifies as a visual deficiency the few attention given to watching that we must learn and deepen: "When we look, normally we only see what surrounds us: four things -the majority of the time very poor- only sights above the middle of the infinity [8]".

Educating the eyes takes on a special relevance, since childhood, being the principal way of knowing what things are. It can develop this ability of what Cossio calls "the art of knowing how to see [4]", which allows to unravel messages of things "knowing how to see them", obtaining essential primary experiences [9]. But in order to do so, it is necessary 
to teach how to look, how to contemplate, it is necessary to educate the deep gaze until we get the attention and possibility of the eye that listens [10], until we get the scrutinizing gaze that artists like Rothko possess. He pretends to advance in visual perception through aesthetics: "How can we get rid of conventional techniques of perception in order to see with the eyes of an artist [11]?" Artists such as Oteiza or Manrique [7] come up with this idea of teaching to see: "In my childhood, the first thing that was photographed by the objectives of my astonished eyes, eager for surprises and saturated with a unique beauty, was the earth". César Manrique used to insist on saying "It is necessary to teach to see", appealing the transforming charge of the eye, educator of the gaze. Eyes that see and that transform what is looked at into the world of ideas [12]. Bozal, who prologues Ortega $\mathrm{y}$ Gasset, is clear in valuing the deepening of the gaze, which can lead us to go deeper into things, from their immanence, beyond their utility or meaning. "The artist is in front of the world and tries to 'reproduce it as a whole' in his intuition... But, in addition, this intuition is productive, the visible is not sought for its importance or meaning, it is sought for itself [12]".

When transferring the gaze of the natural world to works of art [13], the gaze also concentrates on an object and tries to unravel in depth its meanings. They sometimes convey and refer to those of the natural world, but in a different way, since "art tries to discover something hidden from our gaze [14]", at least hidden from the conventional gaze. It is convenient to look close to the object until we achieve the depth of experience that would provide us with a "tactile character [12]". The conformation and education of the scrutinizing gaze tries to understand the objects as a whole, "because the object is always more and different than what was thought in its idea". Even as Whitman [3] and Oteiza [15] suggest, one can search for meanings and messages that objects throw beyond the mere physical plane. That is why it is also necessary to learn by observing what is not seen. In this sense Oteiza goes further by saying "To see what doesn't exist, that's what the artist does. See what doesn't exist [15]". He even believes that "Everything you see is sacred. And what you don't see is a hidden sacredness, a deficiency of our vision [15]". It is through the education of the gaze that we can reach the enabling messages that matter contains in all its dimensions.

Representing the natural world through art produces a transforming circumstance that is implicit to the creative process. The artwork is made like a new object with its own reality, independent of the "duplicated thing [12]", worthy of being contemplated to see, not as a representation of reality, but as the "purely pictorial work [16]". In this way, art is configured as a different approach to enter reality. As with the natural world, the ability to observe and contemplate art awakens consciousness and seeks to generate meaningful experiences that foster personal development, meaningful, and lasting learning [17, 18]. However, we do not always take the time to be looking with our "eyes on the canvas [9]", even though we may be in contact with art regularly, in the sense of looking carefully, unhurriedly, deeply for an extended time and thinking about what we see. It is this gaze of the artist that promotes aesthetic and artistic education, the same that museums containing artworks seek to favor by enabling meaningful experiences [20]. The education of the gaze is thus constituted as one of the ways of "broadening experience through art [...] Look, look deeply"[21], Tàpies will advise us.

\section{The Metaphor for Ortega Y Gasset}

Through gaze we can obtain major experiences, which can even reach the so-called SLE [22], of great significant and transforming power. But learning how to look at art, and more specifically, non-figurative contemporary art is not an easy task. Indeed, it possibly requires training, a practice that can bring as a reward aesthetic enjoyment, a pleasure that Ortega y Gasset consider as "intelligent" [12]. As a tool to point out these significant experiences, the so-called "metaphor" is not a minor resource, but may contain great significant power, for its intellectual efficacy that "comes to touch the confines of thaumaturgy [12]". We could define the word metaphor as a figure in which the meaning of one concept to another, establishing a relationship of similarity or analogy between the two words. Metaphors are images, concepts or ideas that have a subtle relationship between them, and that produce a resizing of the meaning of the object. The metaphor "satisfies us precisely because in it we find a coincidence between two things deeper and more decisive than any similarities [12]". In the metaphor, the gaze and the intellect are connected in a different way. What occurs in the metaphor, Ortega y Gasset describes it as the case of contemporary art, in relation to its power to activate the thought of the visitor, who tries to understand what happens in front of him. "The intellect, as a skillful engineer who by means of dikes gains ground to the sea and drives it away, reduces disorder to an order, chaos to cosmos [12]". The search for meaning and meaning through the gaze finds in the metaphor relations, many of them unexpected and shocking, finds an unexpected turn, a paradox, even an irony, which induces towards a new route of thought towards a new way of thinking about the object. If this does not happen, the metaphor has not been understood, has not worked, remains inconspicuous. The metaphor appeals to a positive discovery that reinforces the "gaze-thought-feeling" route. The metaphor produces a force for the generation of thought and feeling. Ortega y Gasset discovers the potential that metaphor has for art and dedicates an essay on aesthetics to this theme [12]. For Ortega y Gasset "The metaphor is probably the most fertile power that man possesses [12]". He believes that "the aesthetic object finds its elemental form in the metaphor [...] the metaphor is the elemental object, the beautiful cell [12]". This author describes what happens when what is presented in the contemporary work of art (which he alludes to as "new art") is not "recognizable" as an object of the human-natural world (what he calls "ultra-object") and its relationship with aesthetic feelings: 
"With the things represented in the new painting it is impossible to live together: by extirpating their aspect of lived reality, the painter has cut the bridge and burned the ships that could transport us to our usual world. He leaves us enclosed in an abstruse universe, forcing us to deal with objects that cannot be dealt with humanly. We have, therefore, to improvise another form of treatment completely different from the usual way of living things. We have to create and invent unpublished acts that are adequate to those unusual figures. This new life, this life invented after the annulment of spontaneity, is precisely artistic understanding and enjoyment. It does not lack feelings and passions, but evidently these passions and feelings belong to a psychic flora very different from the one that covers the landscapes of our primary and human life. They are secondary emotions that provoke these ultra-objects in our inner artist. They are specifically aesthetic feelings. [12]".

Ortega y Gasset values contemporary art and warns us of the difficulty of escaping from reality when it comes to artistic creation:

"Achieving to build something that is not a copy of the 'natural' and yet possesses some substantivity implies the most sublime gift. "Reality" constantly stalks the artist in order to prevent his evasion. How clever the genius escape is! He must be a Ulysses upside down, who frees himself from his daily Penelope and navigates between pitfalls towards Circe's witchcraft. [12]".

And he culminates that warning considering that the metaphor "facilitates evasion and creates among real things imaginary reefs, the flowering of weightless islands. [12]".

\section{Ortega Y Gasset's Metaphoric Analysis, Transferred to Tàpies' Artwork}

With his artwork, Tàpies created a "weightless island", an object that simulates a real one, a simple and poor cardboard box, but in reality, it is not what it seems. In reality the mimetic object is made of bronze. It pretends to be what it is not. It shouldn't be made with that, made of metal. It is the artwork Composició amb cistella (Composition with basket) (1996) (Figures 1, 2, 3, 4 and 5) which forms part of the permanent collection at the University of Navarra Museum. The work [23] is made from a large cardboard packing box. It is a unique piece, cast in lost wax bronze, weighing close to six hundred kilos and patinated with a tone that simulates cardboard. The work is complemented with black oil strokes, intervened by Tàpies. Its aesthetic invoice is apparently poor, in line with the so-called "Arte Povera" Italian of the sixties of the twentieth century. In this work the objectivity of the material is equivocal. It is a trompe l'oeil: the large cardboard with its wicker basket inside is actually a bronze casting, simulating the texture and color of the cardboard. It simulates a cardboard, but it is not a cardboard. If in the sixties the vulgar object was the protagonist of the installation, now we find the intervention of this material for its excessive exaltation through the enduring bronze. The box has a certain aspect of "hieroglyphic archeology" that is exalted as an idealized icon of the most austere reality. In this way, a new approach to the real is produced, renouncing traditional supports through the apprehension of industrial waste materials or the consumer society, giving importance to chance and irony, reflecting on the frontiers between art and banality.

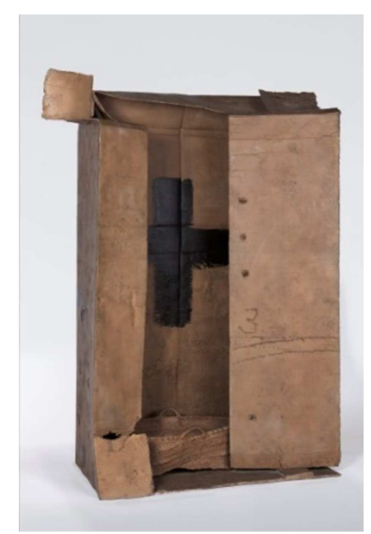

Figure 1. Composició amb cistella (Composition with basket) (1996) (Front). Antoni Tàpies (Photo: Manuel Castells).

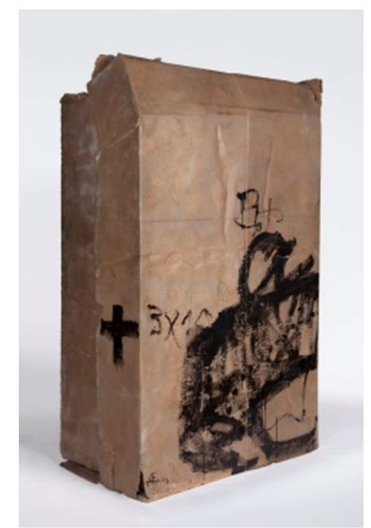

Figure 2. Composició amb cistella (1996) (Back). Antoni Tàpies (Photo: Manuel Castells).

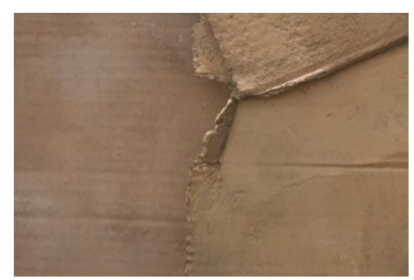

Figure 3. Composició amb cistella (1996) (Detail of the "cardboard" edge). Antoni Tàpies (Photo: Manuel Castells).

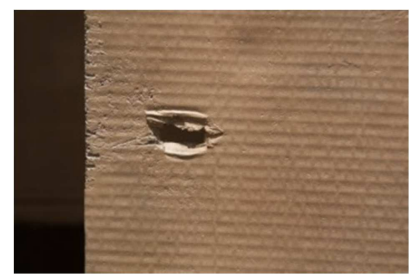

Figure 4. Composició amb cistella (1996) (Detail of the hole). Antoni Tàpies (Photo: Manuel Castells). 


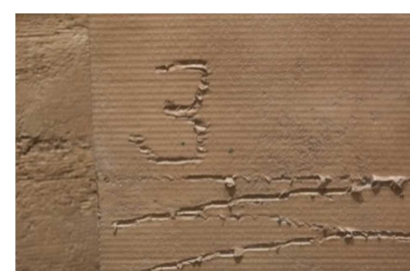

Figure 5. Composició amb cistella (1996) (Detail of the number). Antoni Tàpies (Photo: Manuel Castells).

It is a "figurative work full of symbolism, sense of humor, mystery, drama, and existential work ${ }^{1 "}$. Why and what for does bronze pretend to be cardboard? What are we seeing? A mysterious, majestic and challenging work of art in the face of time, space, norms and archetypes, or an ephemeral useless "rubbish" without meaning? Is it an insult to art and museums? There are many questions raised by Tàpies' work, the unknowns about the object itself, its intention and its way of being. There are many aspects that invite reflection: "what mysteries does it contain inside ${ }^{2}$ ", as well as the duration of cardboard and bronze; the non-value of cardboard and the value of bronze, including its economic value; the difficulty in creating the object of bronze, which would be easily achievable if it were made of cardboard; the existence of only one specimen; the placement of a basket that simulates wicker, a traditional element, but which is actually made of bronze inside the box; the artistic valuation of the object: how much beauty does it contain? Is it a work of art or is it not art at all? is it a work of art or is it not art at all? Vilar helps us to ask the right question: "If two visually indiscernible objects, but one of them is a work of art and the other a mere real commercial object, then what makes one a work of art and the other not? The answer can be found in the informalist movement and in the democratization of art, which promulgates that "anything can be a work of art [24]".

We can find more specific answers to the questions above if we analyze the thought behind Ortega y Gasset's [12] metaphor, applied to Tàpies' work. According to Ortega y Gasset's thought, Tàpies uses metaphor as a conceptual and expressive medium. In his metaphor Tàpies aims to "ennoble the real object [12]" through bronze, material, but not in an aesthetic way, at least not to "ornament and reclaim the beloved reality [12]", since it is not the ornament or the flourishes that Tàpies seems to be looking for. So, what does he seek by simulating such a poor object with such a valuable, so sculptural, so "artistic" material? The answer has to be constructed by each spectator. From the gaze, the machinery of perception is put into operation and synchronized with thought. But not with normal thinking, with the tapiesian metaphor, a superior cognitive ability is sought: the analogy that allows the metaphorical comprehension.

1 M. Jover, Conference given on 06 February 2018 by Mercedes Jover, Director of the Museum of Navarre, on the work Composicio amb cistella (Tàpies, 1996). Cycle of conferences "La obra escogida por". Museo Universidad de Navarra.

2 M. Jover, Conference given on 06 February 2018 by Mercedes Jover, Director of the Museum of Navarre, on the work Composicio amb cistella (Tàpies, 1996). Cycle of conferences "La obra escogida por". Museo Universidad de Navarra.
The aim is to delve into complex relational thinking. The thought redirects the look now scrutinizing more, trying to look for information on the reality of the bronze that is presented to us. It tries to break the visual molds, to enter into the intrigue of the Tapiesian game. But it also tries to understand the possibilities that the box presents and to discover new meanings in that "game of looking" [8] that Tàpies likes so much.

Abril believes that the metaphor is used to "fix attention and emotion in the sense that suits the artist" [25], that suits Tàpies. Tàpies has fled from the natural. Or rather, through the natural. He presents us with another idea, or conjunction of ideas, that make their way beyond the cardboard box. In front of the box, the process described by Ortega y Gasset is generated: "An object that is presented in front of us is, for the moment, nothing more than a multiple solicitation to our activity: it invites us to go through its silhouette with our eyes; to become aware of its tones, some stronger, others softer" [12]. Indeed, the visitor takes an initial visual approach to the box. At the beginning, it is very obvious, the he looks and "recognizes". Or rather he thinks he recognizes. $\mathrm{He}$ is generally very shocked to see a strange cardboard box in the exhibition hall of a museum. Then he feels intrigued, trapped or even indignant. He gets closer, stops looking and tries to dig deeper. He wants to know more. He reads the credential of the work and does not give credit: is it made of bronze? He makes judgments. He wants to recognize and strives to do so. But he also wants to interpret and go beyond what he recognizes. He wants to re-subjectivize its meaning. He wants his thinking to go far beyond the recognizable, beyond the vulgar cardboard box. He wants to interpret art, to advance in the artistic proposal in front of him. And that is going to be an effort. Ortega y Gasset tells us about this eagerness to "recognize" "human [12]" things. The exhibition refers to recognizable objects in contemporary art and advocates learning to look at contemporary art differently, which includes unrecognizable things from the human world [12]. The object, as it is, transfers, through perception, the real world and is installed in the world of the observer, where it becomes an idea subjectivized by the self. This is what is happening with the tapiesian box, where the recognizable and the unrecognizable are conjugated. It is recognized objectively, but what is recognized subjectively is not what is real. It is a simulation, a trick, a paradox, a trompe l'oeil, a sophisticated deception.

Then comes the need to reaffirm our incredulity, to verify that it is not really made of bronze, that we are not being deceived. This is what happens with Tàpies' box: it invites us to be touched, to check, to feel its surface to make sure. Like Saint Thomas, we need to check with touch that the idea we are told is true, that transubstantiation is real, that alchemy has taken place, that cardboard has become metal. Unbelieving eyes appeal to another sense: touch. The impulse to touch is recurrent.

Ready to be reconsidered, thinking now relativizes the initial judgments, and advances intrigued by the "art" that encloses the work. The metaphor has been created, we have 
understood the "game", we have guessed, unraveled and described the "deception". Now we really know what the object is, but something is missing. We don't know its intention. What was it created for, what does it intend to do? Because "after a metaphor has been created, we still ignore its reason [12]".

For Ortega y Gasset the two objects proposed in the metaphor, cardboard and bronze, are "a mere starting point, a material, a sign beyond which we must find identity in a new object" [12]. Primary objects "now become mere properties of a third thing - the sentimental place or the ego form of both [12]". And that third thing exists "in the realm of the aesthetic world, different from the physical world and the psychological world" [12]. There is the object with its own identity, "which is not in the real images" [12] which we could call the "metal-cardboard box". Ortega y Gasset warned us about the "Traditional logic spoke of the tollendo ponens way, in which the negation of a thing is at the same time an affirmation of a new one" [12]. The negation of the cardboard box has created the "metal-cardboard box".

Ortega y Gasset describes this new "thing" with the intimacy of the spectator: "The two images endow the new marvelous body with objective character; its sentimental value lends it the character of depth, of intimacy" [12]. "If, in return, this being or activity of mine is to become an object of perception, it will be necessary for me to stand, let us say so, facing my back to the thing [box], and from it, in the opposite sense to the previous one, to look inside of me and see [the box] becoming unrealized, transforming itself into my activity, into me" [12]. And that activity produces, in the words of Ortega y Gasset, what "we call feeling" [12]. The spectator now possesses the work in his mind and must think about it, unravel the mystery, the sense of paradox, the intention of the metaphor. That proactive feeling is what Tàpies creates in the spectator, beyond his initial indifference towards a simple and poor cardboard box that we could probably find in the garbage, without paying any attention to it. This is the game of looking that Tàpies proposes. The route "gaze-thought-feeling" has been completed.

Ortega y Gasset describes the action mechanism of the metaphor for the case of a cypress. In this case we will replace the cypress with the tapiesian box:

"The mechanism, then, is perhaps the following: it is a question of forming a new object which we will call the "beautiful cypress" [the beautiful box], as opposed to the real cypress [the royal box]. In order to reach it, it has to undergo two operations: the first consists in freeing ourselves from the cypress [of the box] as a visual and physical reality, in annihilating the royal cypress [the royal box]; the second consists in endowing it with this new, very delicate quality that lends it a character of beauty" [12].

In this case Ortega y Gasset connected the metaphor directly to beauty, but Tàpies overcomes this vision by placing beauty on another level, the quality that bronze matter is giving him possibly goes beyond the intention of the search for beauty. In the tapiesian box, beauty is not precisely the protagonist of the metaphor he proposes: "The box for Tàpies is the container of life" ${ }^{13}$.

Continuing with the mechanism of action of the metaphor, for Ortega y Gasset [12] a new object is created that preserves the physical tree [the physical cardboard box] as the mental mold -mold in which a new substance alien to cypress [the cardboard box] is injected [...]", in this case the alien substance is bronze.

When it comes to the possible irony shown by Tàpies' metaphor, the idea of Ortega y Gasset could applied to him. "The irony consists in having an effective personality on which one has the luxury of creating another fictitious one, invented by oneself. This can only be allowed by those who feel very socially secure in their real personality" [12]. This worthless but with personality box, can joke about itself, ironically and put the viewer in a difficult position. Am I kidding you? Am I really valuable? What do I mean? Do I have secrets? Do you want to delve into my mysteries? "What mysteries is a cardboard box going to have?" "And they call this art?" "A cardboard box?" "Oh, it's bronze?" "Then it must be valuable." "But is this art?"4

In these questions, there is a certain unease of those who have not understood the paradox. The resentment of which he has been deceived, almost manipulated by a simple cardboard box exhibited in a museum. We have not succeeded in "penetrating its meaning - the work remains outside us, untamed, foreigner, undefeated -, it remains above us humiliating us" [12]. Then the negative final judgment may appear which "has no basis or evidence: we do not know why the work is bad and by calling it that what we do is defend ourselves from it, irritated" [12]. They are the limitations of real objects, which are presented to us from a biased point of view. The allegory of Plato's cave is repeated in a continuous regression. Perhaps Tàpies' box works as the platonic cave, maybe not entering the cave but showing us the exit of the platonic cave, where using the metaphor proposed by Plato, the view "must adapt now to the light, now to the darkness" [26]. Thus, we get rid of the objects in their most known form, to approach reality through new redescriptions of the objects, some of them surprising, as seen in the tapiesian box. With his sculpture Tàpies has turned towards the internal and the subjective. He focuses on ideas, but through an object that is no longer in itself what it represents, but something else, another idea that must be thought and rethought by each visitor.

Do we want the tapiesian box to "jump on us and give us its secret [12]" as we quickly pass by the Museum's artworks? Whoever wants to understand the box must approach it with humility and respect and provide the means to do so, focusing its attention: "Goethe said that whoever wants to understand the poet must move to the land of the poet [12]". Should we move to the land of the box to understand it, to reveal its multiple meanings? Should we

\footnotetext{
3 M. Jover, Conference given on 06 February 2018 by Mercedes Jover, Director of the Museum of Navarre, on the work Composicio amb cistella (Tàpies, 1996). Cycle of conferences "La obra escogida por". Museo Universidad de Navarra. 4 Comments collected from visitors during guided tours of Tàpies' work. Fuente: Museo Universidad de Navarra.
} 
enter its disturbing interior where even transcendence can inhabit?

What is Tàpies trying to do? With that reflection of the object that is apparently worthless in the middle of a Tàpies Museum, is he ridiculing art [12] or exalting it, looking for new ways and limits of the artistic work? Is he making a very serious joke about art? Or perhaps he is making a very powerful reflection on aesthetic language and its function, or on modern materialism, or on transcendence. It is not easy to reach the conclusion that the work of Tàpies, the alchemical archetype, redeems cardboard and, through aesthetic transubstantiation, elevates it to the height of the heavens. It is not easy to reach the conclusion that it is also a "transcendent box" of totemic character, with a certain halo of worldly idol that transcends the spiritual dimension from its special immanence. The metaphor "pushes us to another world where it is apparently possible"[12]. It is that world of ideas, enabler, where the object ("ultra-object") lives and proposes new messages to us, new possibilities beyond those known or recognized. The enigmatic new object invites us to enter into the unknown, not only in the world of ideas, but it transports us from the physical to the spiritual, to the transcendent plane. The box invites the person "to look inside himself" and has a "great transcendent charge ${ }^{5 "}$.

Perhaps Kiedler's sentence in which he says "There are great works with minor themes [12] and great themes in minor works" is fully applicable to the metaphor proposed in Tàpies' work. Perhaps this idea is sublimated in the Tapiesian metaphor. The visitor is confused. Is it a great work or a minor work? Does it speak to us of a theme of no importance or does it refer to one of the great universal philosophical themes, such as human transcendence?

\section{Conclusions}

1. There is a first level of relationship between people and reality that includes perceptions of the messages provided by objects. Some are more immediate because they are realized through the physical. Others, less conspicuous, are produced through the physical, but overcome it to transcend into the metaphysical. Aesthetics, as a form of human interaction with reality, can help in the discovery and interpretation of these messages.

2. Education of the eyes can help unravel the messages reality provides to each person. It is convenient to learn to look deeply, with a sharp, scrutinizing, analytical, inquiring look, without being conditioned by haste. It is a question of educating the gaze to be able to contemplate, with the depth that it requires, reality and its multiple languages, among them the aesthetic one.

3. Art seeks languages to deepen understanding of reality, often with the intention of going beyond what the eyes

5 M. Jover, Conference given on 06 February 2018 by Mercedes Jover, Director of the Museum of Navarre, on the work Composicio amb cistella (Tàpies, 1996). Cycle of conferences "La obra escogida por". Museo Universidad de Navarra. see. To this end, the metaphor is configured as a powerful aesthetic resource of great significant power that, through superior cognitive abilities such as comparison, analysis, synthesis and conclusion, achieves a generation of thought and intellectual efficiency that tries to facilitate the understanding of the world.

4. Ortega y Gasset's thought on the relationship between metaphor and art is fully applicable to the work Composició amb cistella by Antoni Tàpies. The artistic and creative work of Tàpies, who uses the metaphor as an aesthetic language, can reinforce the route "gazethought-feeling" and serve to help increase attention to what is looked at and to understand in a profound way, connecting gaze and intellect in a different way, making meaningful experiences possible.

5. Tàpies is configured as a model to be followed in the education of the scrutinizing, analytical and synthetic gaze, since through a metaphor he can concretize his "Look, look deep", with which he tries to help unravel what reality is, what things are.

6. In his work Composició amb cistella (Composition with a basket), Tàpies uses a metaphor as a paradoxical figure that activates "I see-think-I wonder". Through his aesthetics he manages to engage the observer in the task of unraveling the mysteries contained in his work. The work can generate questions about the appearance and essence of what things are, helping to reformulate new meanings that surpass those of the past.

\section{References}

[1] Abram, D. (2010), Becoming animal: An earthly cosmology. New York: Pantheon Books, pp. 49-50.

[2] Clayton, S. y Myers, G. (2015), Conservation Psychology. Understanding and promoting human care for nature. Oxford: Wiley Blackwell.

[3] Whitman, W. (1955), Hojas de hierba [Leaves of Grass], Barcelona: Mayol Pujol, p. 136.

[4] Cossio, M. B. (1929), De su jornada (fragmentos). Madrid: Imp. de Blass, pp. 6-7.

[5] Arnheim, R. (1969), Visual Thinking. Berkeley and Los Angeles, California: University of California Press.

[6] Carson, R. (1956), El sentido del asombro. Madrid: Ediciones Encuentro.

[7] Manrique, C. (2005), César Manrique la palabra encendida. Selección de textos e introducción de Fernando Gómez Aguilera. León: Universidad de León. Pástica \& palabra, p. 29.

[8] Tàpies, A. (1967), "El joc de saber mirar". Cavall Fort, 82.

[9] Yenawine, P. (2013), Visual thinking strategies. Using art to deepen learning across school disciplines. Cambridge: Harvard education press, pp. 6-7.

[10] Palazuelo, P. (2011), Palazuelo. La línea que sueña. Galería de arte Fernández-Braso, Madrid, p. 27. 
[11] López-Remiro, M. (2007), Mark Rothko. Escritos sobre arte (1934-1969). Barcelona: Paidós Estética, p. 18.

[12] Ortega y Gasset, J. (2010) (1 ${ }^{\text {a }}$ edition 1925), España invertebrada. La deshumanización del arte y otros ensayos de estética. Centro editor PDA: Barcelona, pp. 186, 134-136, $178,183,254,222,183,253,174,175,183$.

[13] Berger, J. (1972), Ways of Seeing. London: Penguin books.

[14] Viber, J. (2016), Presentación de la exposición "Aurelia immortal". Museo Universidad de Navarra.

[15] Merino, J. L. (2008), Habla Oteiza. Bilbao: Editorial Avance Proyectos. Colegio Oficial de Arquitectos Vasco-Navarro, p. 40 .

[16] Malévich, K. (2008), Escritos. Madrid: Síntesis, p. 235.

[17] Ausubel, D. P. (1968), Educational Psychology: A Cognitive View. New York: Holt, Rinehart and Winston.

[18] Novak, J. D., and D. B. Gowin. (1984), Learning How to Learn. Cambridge: Cambridge University Press.

[19] Pastor, M. I. (2004), Pedagogía museística: Nuevas perspectivas y tendencias actuales. Barcelona: Ariel Patrimonio, p. 44.

[20] Priem, K. and Mayer, C. (2017), "Learning how to see and feel: Alfred Lichtwark and his concept of artistic and aesthetic education". International Journal of the History of Education, 53 (3), 199-213.

[21] Acedo, N. (2015), Arte contemporáneo y percepción activa: reflexión crítica frente a contemplación, 65-76. In: Llano, A. (Ed.). (2015), El arte más allá de sí mismo, 77-89. Madrid: Biblioteca nueva.

[22] Herrmanns, R. (1970). The Most Beautiful Painting in the World. Exeter: Wheaton.

[23] Chawla, L. (1998), "Significant Life Experiences Revisited: a review of research on sources of environmental sensitivity". Environmental Education Research, 4 (4), pp. 369-382. doi. org/10.1080/1350462980040402.

[24] Olmo, S. (ed.). (2015), Colección María Josefa Huarte. Abstracción y modernidad [Abstraction and Modernity]. Pamplona: University of Navarra Museum.

[25] Vilar, G. (2007), Desartizacion. Paradojas del arte sin fin. Salamanca: Ediciones Universidad de Salamanca, p. 191.

[26] Abril, M. (1926), "Itinerario ideal del nuevo arte plástico". Revista de Occidente, Diciembre, 343-367.

[27] Carbonell, C. (2015), Platón visita una exposición de Malévich. El arte en la ampliación de la experiencia filosófica, 91-109. In: Llano, A. (Ed.). (2015), El arte más allá de sí mismo, 77-89. Madrid: Biblioteca nueva, p. 104. 